\title{
ISSUE OF ACTUAL CHRONOLOGY OF A ROMANESQUE CHAPEL AT THE WLEŃ CASTLE (LOWER SILESIA, POLAND) IN THE LIGHT OF MORTAR RADIOCARBON DATING
}

\author{
JACEK MICHNIEWICZ ${ }^{1}$, DANUTA NAWROCKA ${ }^{1}$, ANNA PAZDUR ${ }^{2}$ and MARTA ŻURAKOWSKA ${ }^{3,4}$ \\ ${ }^{1}$ Institute of Geology, Department of Dynamic and Regional Geology, \\ Adam Mickiewicz University, Maków Polnych 16, 61-606 Poznan, Poland \\ ${ }^{2}$ Department of Radioisotopes, Institute of Physics, Silesian University of Technology, \\ Krzywoustego 2, 44-100 Gliwice, Poland \\ ${ }^{3}$ Institute of Civil Engineering, Department of Geotechnics and Engineering Geology, \\ Poznan University of Technology, Piotrowo 5, 60-965 Poznań, Poland \\ ${ }^{4}$ Department of Geographical and Earth Sciences, University of Glasgow, \\ Lilybank Gardens, Glasgow, G12 $8 Q Q$ UK
}

\begin{abstract}
The presented work discusses results of radiocarbon dating of lime mortars sampled from walls of a Romanesque chapel at the Wlen castle. Considering a homogeneous structure of the mortars, an attempt to determine the chronology was made. Radiocarbon dating was carried out both on carbonate binders and laboratory-selected charcoals from the mortars. According to obtained data, charcoal ages are older than the age of the binders. Assuming the $12^{\text {th }}$ century chronology of the chapel's erection to be correct, it was found that the applied method did not provide the result which is consistent with archaeological estimations.
\end{abstract}

Keywords: radiocarbon dating, Castle Wleń, lime mortars, charcoal

\section{INTRODUCTION}

The paper presents results of the research on the radiocarbon age of lime mortars sampled from a ducal chapel's walls at the Wlen castle (Fig. 1). The research is a continuation of previous studies on spatial development of the castle from the Middle Ages to the Renaissance, which were based on chemical analysis of lime mortar samples and on determination of petrographic composition of aggregate (Michniewicz, 1997). The results obtained then indicated an entire distinction between Romanesque mortars of the ducal chapel's walls, ramparts and remaining buildings of the castle.

A problem with application of the radiocarbon method for precise dating of carbonate binders, their relative overestimation - connected with presence of so called "dead carbon" - and then radiocarbon rejuvenation - resulted from their secondary recrystallization, has not

Corresponding author: D. Nawrocka

e-mail: danutamich@go2.pl

ISSN 1897-1695 (online) (C 2007 GADAM Centre,

Institute of Physics, Silesian University of Technology.

All rights reserved. been totally solved (Folk and Valastro, 1979; Zouridakis et al., 1987; Heinemeier et al., 1997; Sonninen and Jungner 2001; Nawrocka et al., 2005). Two determinants are essential in providing radiocarbon ages of binders: deadburned lime materials and completed slaking process. In the past, these requirements usually were not realized and, consequently, obtained radiocarbon dating of mortars was older or younger than the actual age (Nawrocka et al., 2005). The homogeneous structure of the mortars the castle chapel's walls found by petrographic analysis and low aggregate content indicated, that these mortars might be a perfect material for the ${ }^{14} \mathrm{C}$ method.

According to archaeological investigations, the castle chapel, together with the rampart, a residential building and a hexagonal keep are the oldest structures of the castle (Buśko, 1998). It is difficult to reconstruct precisely the castle history, however, historians and archaeologists connect the first masonry structures with Boleslaw I the Tall (Boleslaw Wysoki: 1127-1201), a grandson of Boleslaw III Wrymouth (Boleslaw Krzywousty). 


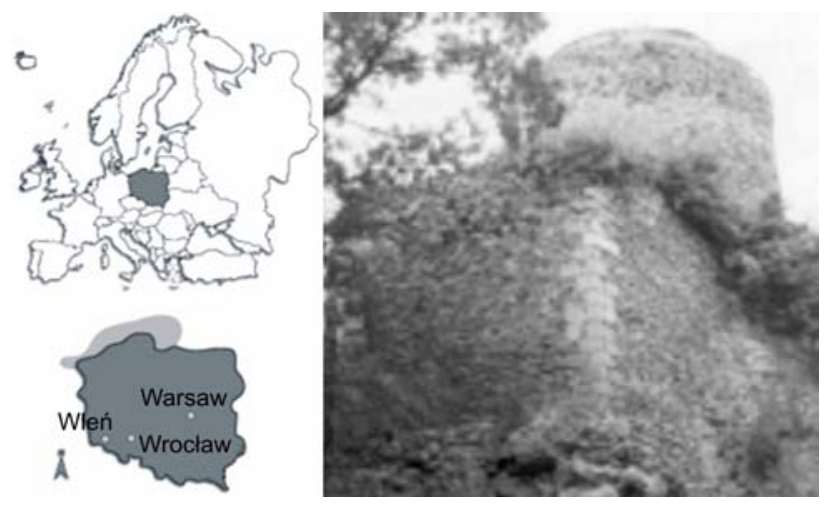

Fig. 1. Location: Wleń Town, Lower Silesia province (SW Poland); front elevation of Wleń castle

\section{SUBJECT OF THE ANALYSIS AND APPLIED METHOD}

The analyses were carried out on mortar samples taken from the chapel's walls:

- K160/4 - the base of the rood-arch, a structure of yellow sandstone ashlars;

- K157/1, K1/93 - the northern wall of the church, a structure of broken greenstone ashlars.

Two samples of carbonate binder were analyzed and two samples of laboratory-selected charcoals were analyzed as well (cf. Table 1). The conventional ages of the binder were obtained with the use of gas proportional counters (the GPC) in the Gliwice Radiocarbon Laboratory ("S" samples, Gd-15369 and Gd-17105; Pazdur et al., 2000, 2004). Dating of the charcoals was carried out with the use of accelerator technique (AMS) in the Radiocarbon Laboratory in Poznań ("W" samples, Poz-5091 and Poz-5092; Goslar et al., 2004).

\section{THE RESULTS}

The obtained conventional radiocarbon data and the intervals of calendar years, together with probability for 68 and 95\% confidence intervals are presented in Table 1. The distribution of the probability density function of the calendar age for individual samples were obtained with the use of the OxCal v.3.10 calibration software (Bronk Ramsey 2005). The distributions are presented in Fig. 2, and also in numerical form in Table 1.

\section{DISCUSSION ON THE RESULTS}

In the obtained conventional data one may observe a relatively high uncertainty of binder chronology indicated by the GPC technique (dates Gd-15369 i Gd-17105) and high precision of charcoals age obtained by the AMS technique (dates Poz-5091 and Poz-5092, cf. Table 1). This fact exerts an influence on the form of the probability function (cf. Fig. 2) and width of most probable intervals of calendar age both at the 68 and $95 \%$ confidence levels.

Moreover, those intervals are widened owing to unambiguous value of the calibration curve observed in the discussed time span. It is particularly clear in AMS precise date Poz-5092, $1185 \pm 35$ BP, where the width of the most probable interval of calendar age at the 68 and $95 \%$ confidence levels equals, respectively, 110 and 140 years.

While considering the results of data calibration at the 95\% confidence level, calendar age intervals indicate a certain shift of the charcoal ages in comparison with the binder ages, towards higher values. The significance of differences of binder and charcoal ages may be questionable due to a high measurement uncertainty of radiocarbon dates of binders samples. The estimated calendar age intervals of charcoal fragments taken from mortar and determined precisely with the AMS technique do not cover the $12^{\text {th }}$ century (cf. Table 1), i.e. the chronology of the chapel established on the basis of the historical and archaeological survey. Fig. 2 also shows that the ages of charcoals are older in comparison with binder ages, what may indicate using old wood in burning process. Therefore we continue the interpretation of radiocarbon results on binder samples only. In the case of the studied castle we know from the reliable historical sources (after Buśko, 1998), that the Wlen church existed from 1177AD to $1239 \mathrm{AD}$. These events define a terminus ante quem (TAQ) - none dated sample can be older than 1230AD, and terminus poste quem (TPQ) - none dated sample can be younger than $1177 \mathrm{AD}$. We combined radiocarbon dates and the above-mentioned information using option

Table 1. Measurement results of conventional radiocarbon age of mortar binder samples ("S" samples) and charcoals from mortars ("W" samples) and intervals of calendar years for 68 and 95\% confidence intervals together with their probability, determined with the use of the OxCal v.3.10 (Bronk Ramsey, 2005). Approximate age established by archaeological research for Romanesque church mortars: $12^{\text {th }}$ Century.

\begin{tabular}{|c|c|c|c|c|c|c|}
\hline Sample Name & & Lab. No & ${ }^{14} \mathrm{C}$ Age (BP) & $\begin{array}{l}\delta^{13} \mathrm{C} \\
(\%)\end{array}$ & $\begin{array}{c}\text { Cal. Age } \\
\text { (68.2\% conf. intervals) } \\
\text { (AD) }\end{array}$ & $\begin{array}{c}\text { Cal. Age } \\
\text { (95.4\% conf. intervals) } \\
\text { (AD) }\end{array}$ \\
\hline $\mathrm{K} 1 / 93 / \mathrm{W}$ & $S$ & Gd-15369 & $1030 \pm 80$ & -12.5 & $\begin{array}{rr}890-1050 & (54.1 \%) \\
1080-1150 & (14.1 \%)\end{array}$ & $810-1210 \quad(95.4 \%)$ \\
\hline K160/4/W & S & Gd-17105 & $940 \pm 130$ & -13.2 & $980-1230 \quad(68.2 \%)$ & $750-1300 \quad(95.4 \%)$ \\
\hline $\mathrm{K} / 160 / 4$ & W & Poz-5092 & $1185 \pm 35$ & -26 & $780-890 \quad(68.2 \%)$ & $\begin{array}{lr}710-750 & (3.3 \%) \\
760-900 & (82.8 \%) \\
910-970 & (9.3 \%)\end{array}$ \\
\hline $\mathrm{K} / 157 / 1$ & W & Poz-5091 & $1035 \pm 30$ & -21.9 & $985-1025 \quad(68.2 \%)$ & $\begin{array}{lr}890-920 & (5.6 \%) \\
940-1040 & (89.8 \%)\end{array}$ \\
\hline
\end{tabular}




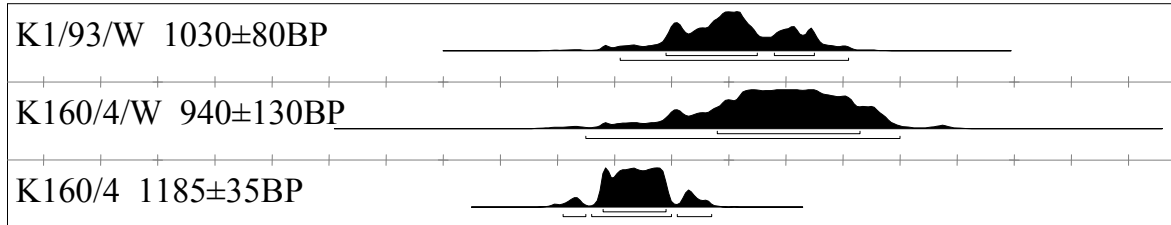

K157/1 1035 $\pm 30 \mathrm{BP}$

$4+\mathrm{Ca}$

CalBC/CalAD

$500 \mathrm{CalAD}$

$1000 \mathrm{CalAD}$

$1500 \mathrm{CalAD}$
Fig. 2. The distribution of the probability density function of the calendar age for binder and charcoal samples obtained with the use of the OxCal v.3.10 calibration software.

Calibrated date

TAQ and TPQ in OxCal programme. The results of the calibration of mortar binders seem to be congenial to historical data. The age of binders is compatible with the archaeological and historical estimations, but it is not absolute confirmation of these premises, for the sake of a large width of confidence intervals.

It should be added, that the binder calendar age obtained on the basis of calibration of the conventional radiocarbon date should determine the chapel chronology more precisely than the charcoal age. On the basis of petrographic observations, the whole radiocarbon contained in the binder seems to originate from atmospheric carbon dioxide during the setting of the lime mortar. The charcoal age indicates probably the age of wood used in lime burning. It depends both on wood provenance and its burnt fragments. Thus, the charcoals age - older then the binder - is not surprising.

\section{CONCLUSIONS}

The obtained calendar age intervals indicate a certain displacement of the charcoals age, in comparison with the binders age, towards its higher value. The significance of the differences is not too high due to relative high measurement uncertainties of binder dating obtained with the GPC technique, resulting from a small quantity of accessible material to dating with the conventional method and ambiguity of the calibration curve. The charcoal ages are older than binders, possibly indicating that the old wood fragments were use in burning process.

The castle chapel, according to archaeological historical evidence, belongs to the oldest masonry structures of the castle, ascribed to Boleslaw I the Tall. Assuming that the $12^{\text {th }}$ century is the actual date of the chapel erection, one should conclude, that charcoal radiocarbon dating fails to confirm the historical premises. The calendar age interval of the binder seems to be more congenial to archaeological historical expectations and premises referring to the chronology of the chapel's erection, but because of a high measurement uncertainty (a large width of confidence intervals) they cannot absolutely confirm the historical data.

\section{ACKNOWLEDGEMENTS}

We sincerely thank Piotr Buczkowski, MS, for help and his devoted time. We express thanks to Prof. Tomasz Goslar, Dr. Justyna Czernik and the employees of the teams from the ${ }^{14} \mathrm{C}$ laboratories in Gliwice and Poznan.

The research was partially supported by the Polish Scientific Research Committee (Komitet Badań Naukowych), grant no 3 P04D 05325.

\section{REFERENCES}

Bronk Ramsey C, 2005. OxCal v.3.10. http://www.rlaha.ox.ac.uk/ orau/calibration.html

Buśko C, 1998. Die Burg Lahn im 12.-17. Jahrhundert. Questiones Medii Aevi Novae 3: 273-285.

Folk RL, Valastro S, 1979. Dating of lime mortar by ${ }^{14} \mathrm{C}$. In: Berger R and Suess H, eds, Radiocarbon Dating. Proceedings of the Nonth International Conference Los Angeles and La Jolla 1976. Berkeley, Los Angeles: University of California Press: 721-730.

Goslar T, Czernik J, Goslar E, 2004. Low-energy ${ }^{14} \mathrm{C}$ AMS in Poznan Radiocarbon Laboratory, Poland. Nuclear Instruments and Methods in Physics Research Section B 223: 5-11.

Heinemeier J, Jungner H, Lindroos A, Ringbom A, von Konow $\mathrm{T}$ and Rud N, 1997. AMS ${ }^{14} \mathrm{C}$ dating of lime mortar. Nuclear Insttruments and Methods in Physics Research B 123: 487-495.

Michniewicz J, 1997. Stone materials, mortars and ceramics applied in the Middle Ages and Renaissance on the example of the castle in Wleń. PhD thesis. Adam Mickiewicz University, Institute of Geology, Poznan, Poland. (in Polish).

Nawrocka D, Michniewicz J, Pawlyta J, Pazdur A. 2005. Application of radiocarbon metod for dating of lime mortars. Journal on Methods and Applications of Absolute Chronology. Geochronometria 24:109-115.

Pazdur A, Fogtman M, Michczynski A and Pawlyta J, 2004. Precision of ${ }^{14} \mathrm{C}$ dating in Gliwice Radiocarbon Laboratory. FIRI Programme. Geochronometria 22.

Pazdur A, Michczynski A, Pawlyta J and Spahiu P, 2000. Comparision of the radiocarbon dating methods used in the Gliwice Radiocarbon Laboratory. Geochronometria 18: 9-14.

Sonninen E and Jungner H, 2001. An improvement in preparation of mortar for radiocarbondating. Radiocarbon 43(2A):271-273.

Zouridakis N, Saliege JF, Person A and Filippakis SE, 1987. Radiocarbon dating of mortars from ancient greek palaces. Archaeometry 29(1): 60-68. 